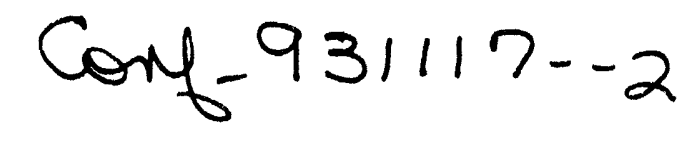

PNL-SA-23289

ANALYSIS OF MID-TROPOSPHERIC CARBON MONOXIDE

DATA USING A THREE-DIMENSIONAL GLOBAL

ATMOSPHERIC CHEMISTRY NUMERICAL MODEL

R. C. Easter

R. D. Saylor

E. G. Chapman

November - December 1993

Presented at the

20th International Technical Meeting on

Air Pollution Modelling and its Application November 29 - December 3, 1993

Valencia, Spain

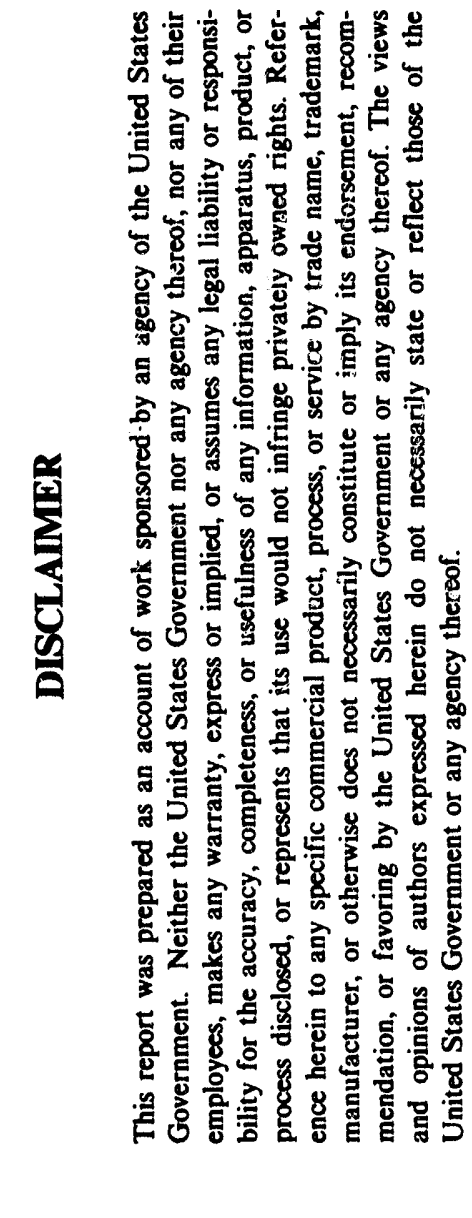

Pacific Northwest Laboratory

Richland, Washington 99352 


\title{
ANALYSIS OF MID-TROPOSPHERIC CARBON MONOXIDE DATA USING A THREE-DIMENSIONAL, GLOBAL ATMOSPHERIC CHEMISTRY NUMERICAL MODEL
}

\author{
Richard C. Easter, Rick D. Saylor, and Elaine G. Chapman \\ Earth and Environmental Sciences Center \\ Pacific Northwest Laboratory \\ Richland, WA 99352
}

\section{INTRODUCTION}

Carbon monoxide is an important atmospheric trace species. It has long been recognized as a major contributor to urban air quality and in high concentrations is known to adversely affect health (Seinfeld, 1986). $\mathrm{CO}$ is the third most abundant carbon-containing species in the atmosphere and its reaction with hydroxyl radical $(\mathrm{OH})$ represents a $2000-3000 \mathrm{Tg} / \mathrm{yr}\left(1 \mathrm{Tg}=10^{12} \mathrm{~g}\right)$ source of carbon dioxide. On a global basis, $\mathrm{CO}$ is the dominant sink for $\mathrm{OH}$ (Logan et al., 1981) and therefore plays a significant role in the troposphere's overall oxidative capacity. Furthermore, depending on the local abundance of nitrogen oxides, $\mathrm{CO}$ can participate in reactions that either increase or decrease the formation of tropuspheric ozone (Logan et al., 1981).

Several three-dimensional modeling studies have been attempted in the past to better understand the global distribution of CO. The earliest attempt was made by Kwok et al. (1971). In their simulation, CO was transported within a GCM as an inert tracer and allowed to advect within the troposphere over 30 days during a simulated November-December time period. They performed experiments with and without vertical CO transport by cumulus convection and found that around 10 percent of their model's global-mean vertical transport occurred through upward cumulus motion. Peters and Jouvanis (1979) developed a global CO and $\mathrm{CH}_{4}$ transport model that included chemical kinetics calculations and was separated from a parent GCM such that observed meteorological data for a specified time period could be used to drive a simulation. From their simulations they estimated a residence time for $\mathrm{CO}$ of $0.21 \mathrm{yr}$. The same model was used by Kitada and Peters (1982) to generate global estimates of the distribution of $\mathrm{OH}$ concentrations which compared favorably with the limited measurements available at that time. Pinto et al. (1983) used a GCM tracer model with simple chemistry to study the climatological $\mathrm{CO}$ budget and its global distribution. They suggested that, in addition to fossil fuel combustion and $\mathrm{CH}_{4}$ oxidation sources of $\mathrm{CO}$, a large low latitude source of $1300 \mathrm{Tg} / \mathrm{yr}$ was necessary to account for observed CO magnitudes and isotopic abundances. Crutzen and Zimmerman (1991) performed a set of global three-dimensional simulations to study the impact of changing anthropogenic emissions of $\mathrm{CO}, \mathrm{CH}_{4}$, and $\mathrm{NO}_{\mathbf{x}}$ from pre-industrial values to present-day levels on the atmosphere's total oxidative capacity. They concluded that since the beginning of the industrial revolution a large increase in $\mathrm{CO}$ concentrations has occurred, predominantly in the northern hemisphere, which has resulted in a substantial decrease of global OH concentrations. In Saylor and Peters $(1990,1991)$, the original model of Peters and Jouvanis (1979) was used to analyze CO data from the November 1981 mission of NASA's Measurement of Air Pollution from Satellites (MAPS) program. A three-dimensional simulation was performed for the November 1981 time period and the model's results were compared with the mid- to upper-tropospheric data of Reichle et al. (1986). They found good agreement between the model's results and the observations of the MAPS experiment. Simulations performed without the inclusion of fossil fuel combustion emissions indicated that emissions from biomass burning may be exerting a significant role in global $\mathrm{CO}$ distributions.

The purpose of the current work is to extend the results of Saylor and Peters $(1990,1991)$ to the October 1984 MAPS CO dataset. The data obtained during the second MAPS mission was much more complete in global coverage and thus provides an excellent opportunity for comparison with model simulations. The primary objective of this study is to examine the data of the 1984 MAPS mission, using a three-dimensional model as an interpretive tool. We have performed global, three-dimensional simulations of CO transport and chemistry for September-October, 1984, the time period during which the MAPS experiment was conducted. 


\section{MAPS MEASUREMENTS OF TROPOSPHERIC CARBON MONOXIDE}

The Measurement of Air Pollution from Satellites (MAPS) experiment was designed by NASA to investigate the global distribution of tropospheric CO (Reichle et al., 1986; Reichle et al., 1990). Two experiments have been conducted in this program - the first during November 1981 and the second during October 1984. In each experiment a nadir-viewing gas filter radiometer was placed onboard the U.S. space shuttle and mid- to upper-tropospheric $\mathrm{CO}$ data were obtained. Details of the measurement technique and instrumentation used during these experiments can be found in Reichle et al. (1986, 1990). Carbon monoxide measurements were made between $38^{\circ} \mathrm{N}$ and $38^{\circ} \mathrm{S}$ during the 1981 experiment, while a broader coverage of $57^{\circ}$ $\mathrm{N}$ to $57^{\circ} \mathrm{S}$ was obtained during the 1984 experiment. The MAPS measurements represent the first nearly simultaneous set of trace tropospheric species data obtained with such widespread global coverage. In this work we concentrate our analysis on the second MAPS experiment, although some of the major features of the 1984 dataset are also common to the 1981 data.

The second MAPS experiment was performed during October 5-13, 1984; Reichle et al. (1990) present results from this dataset. In comparing remotely sensed $C O$ mixing ratios from the MAPS experiment with in situ CO measurements taken in the mid-troposphere by aircraft sampling, Reichle et al. (1990) concluded that the MAPS CO data are systematically too low by 20-40 percent. Taking this bias into account, several largescale features of the MAPS dataset are described in the following. Significant areas of elevated CO mixing ratios (> $80 \mathrm{ppb)}$ occur over southem Africa, central South America and central and eastern Asia. Smaller areas of high $\mathrm{CO}$ values occur over the southern Indian ocean, southern Australia and New Zealand, the North Atlantic, and the far northern and southem reaches of the Pacific ocean. Just as striking as these areas of high $\mathrm{CO}$ values are the vast areas of very low $\mathrm{CO}$ that occur over the central Pacific and in a band stretching from Central America across the Allantic, over the Sahara, and into western Asia. Some these features are readily explained by correlation with major source areas of $\mathrm{CO}$ emissions. For example, the maxima which occur over southern Africa and central South America have been linked to biomass burning activities (Watson et al., 1990 and Connors et al., 1991). However, other features, such as the high values over the southern Indian ocean and over the northeastern portion of Asia, are not as easily linked to known areas of large CO emissions. Also puzzling is the lack of a well-defined plume associated with North America, which is known to be a significant source of anthropogenic $\mathrm{CO}$.

\section{MODEL DESCRIPTION}

The Global atmospheric Chemistry Model (GChM) is an Eulerian, three-dimensional model that simulates the emission, transport, chemical transformation and surface interactions of tropospheric trace species. It has been used previously to investigate the impact of fair weather cloud venting processes on the long-range transport of $\mathrm{CO}$ and $\mathrm{CH}_{4}$ (Luecken et al., 1989) and to estimate the long-range transport of sulfur from North America and Europe to the North Atlantic (Luecken et al., 1991).

\section{Governing Equation}

The mass conservation equation for a gas-phase atmospheric species as simulated by GChM is given by

$$
\begin{aligned}
& \frac{\partial r_{i}}{\partial t}+\frac{u}{a \cos \theta} \frac{\partial r_{i}}{\partial \phi}+\frac{\nu}{a} \frac{\partial r_{i}}{\partial \theta}+w_{c} \frac{\partial r_{i}}{\partial \sigma}= \\
& \frac{1}{p_{a} a^{2} \cos ^{2} \theta} \frac{\partial}{\partial \phi}\left(p_{c} K_{n} \frac{\partial r_{i}}{\partial \phi}\right)+\frac{1}{p_{a} a^{2} \cos \theta} \frac{\partial}{\partial \theta}\left(p_{c} \cos \theta K_{h} \frac{\partial r_{i}}{\partial \theta}\right)+\left(\frac{M_{a} g}{p_{c}}\right)^{2} \frac{\partial}{\partial \sigma}\left(c^{2} K_{t} \frac{\partial r_{i}}{\partial \sigma}\right)+R_{i}+C T_{i}
\end{aligned}
$$

where $\phi$ and $\theta$ are longitude and latitude respeciively, $\sigma$ is the vertical coordinate expressed in terms of normalized pressure

$$
\sigma=p / p_{s}
$$

$p$ is the pressure at the current vertical level, and $p_{s}$ is the corresponding pressure at the surface. Further, $r_{i}$ is the mixing ratio of species $i, u$ and $v$ are the curvilinear velocity components toward east and north, respectively, $w_{\sigma}$ is the vertical velocity component in the $\sigma$ coordinate system, $a$ is the mean radius of the earth, $g$ is the gravitational acceleration, $M_{a}$ is the molecular weight of air, $K_{h}$ and $K_{2}$ are the horizontal and vertical components of the eddy diffusivity tensor, $K_{i}$ represents chemical production (or loss) of species $i$, and $C T_{i}$ is the change of species $i$ per unit time resulting from convective cloud transport. The boundary conditions applied to these equations account for the inflow and outflow of material from the model domain through surface exchange, emission of trace species at the surface, and advection across the model's upper boundary. 


\section{Meteorology and Model Transport}

Meteorological data from the European Centre for Medium-Range Weather Forecasting (ECMWF) for September 1 through October 15,1984, were used to drive the GChM simulations reported here. The ECMWF data for this time period are provided on a $1.875^{\circ}$ latitude-longitude grid with 16 vertical levels and at 6-h time intervals. The data include horizontal winds, vertical velocity, temperature, humidity, cloud cover, and several surface parameters. The current GChM simulations used the lowest 14 levels (surface to $100 \mathrm{hPa}$ ) and a $3.75^{\circ}$ horizontal grid resolution.

Advective transport in the model is calculated using a version of the Bott algorithm (Easter, 1993) with 1-h time steps. Vertical turbulent transport is calculated with an implicit in time, centered in space finite difference algorithm. Spatially and temporally varying eddy diffusivity coefficients are calculated according to the procedure of Carmichael (1979). Horizontal turbulent transport is neglected in these simulations.

The parameterization of convective clouds is based on the model of Walcek and Taylor (1986) and is similar to that used in the Regional Acid Deposition Model (Chang et al., 1987). When convective clouds are present over a grid cell, the convective cloud volume (determined by cloud base, cloud top, and areal coverage) is filled with air from below cloud base plus air entrained from the cloud top model level. This takes place over the convective cloud lifetime (assumed $1 \mathrm{~h}$ ), and then the cloud dissipates. The process of filling the cloud volume. transports trace species from below cloud base to higher altitudes. The amount of vertical transport is dependent on the cloud volume and thus the cloud areal coverage (cloud base and cloud top are determined by the temperature and moisture vertical profiles). In the simulations presented here, the areal coverage for convective clouds was taken to be the total cloud coverage from the ECMWF analyses when that coverage was below $35 \%$. As discussed below, convective transport has a major impact on the simulated $C O$ concentrations at upper model levels. We plan to investigate other methods for parameterizing convective transport.

\section{Chemistry}

The version of GChM used for this work accounts for the kinetic reactions of $\mathrm{CO}$ and $\mathrm{CH}_{4}$ that occur in the remote troposphere. The gas-phase mechanism of Lelieveld and Crutzen (1990) has been used as the basis for GChM chemical transformations. To reduce the computational burden of the chemical calculations within the model, several simplifying assumptions and techniques have been implemented. First, a latitude-altitude distribution of ozone mixing ratios is specified within the model, based on the climatological distribution of Fishman and Crutzen (1978). Further, $\mathrm{NO}_{\mathrm{x}}$ vertical profiles for each grid column are calculated during the simulation based on the implementation of Peters and Jouvanis (1979) and Kitada and Peters (1982). In their formulation, a $\mathrm{NO}_{\mathbf{x}}$ vertical profile is specified for each vertical column based on the $\mathrm{CO}$ emissions that are specified for that surface grid cell. Since $\mathrm{CO}$ emissions in each grid cell are time varying, the $\mathrm{NO}_{x}$ profiles generated by this methodology change dynamically during simulation runtime. Finally, the pseudo-steady-state approximation (PSSA) is imposed at each grid point for all species in the chemistry mechanism except for CO and $\mathrm{CH}_{4}$. The combination of prescribed $\mathrm{NO}_{\mathrm{x}}$ and $\mathrm{O}_{3}$ distributions and the application of PSSA allows a set of algebraic relationships to be formulated for the calculation of $\mathrm{OH}$ radical concentrations. A simple iterative procedure is used to solve the algebraic equations for $\mathrm{OH}$, which is then used to integrate the chemical rate equations of $\mathrm{CO}$ and $\mathrm{CH}_{4}$. To test the accuracy of this simplification procedure, a series of box model chemistry simulations were performed in which the simplified chemical scheme was compared to a full integration of the rate equations with no PSSA applied. The error in $\mathrm{CO}$ and $\mathrm{CH}_{4}$ mixing ratios calculated by the simplified procedure as compared to the full integration was less than 1 percent for most $\mathrm{NO}_{\mathrm{x}}$ and $\mathrm{O}_{3}$ conditions.

\section{$\mathrm{CO}$ and $\mathrm{CH}_{4}$ Emissions}

Due to the simplifications made to the chemical transformation calculations, only the emissions of $\mathrm{CO}$ and $\mathrm{CH}_{4}$ were required for the current GChM simulations. Both $\mathrm{CO}$ and $\mathrm{CH}_{4}$ emissions data were taken from the work of DeHaven (1980) and updated based on current knowledge. Table 1 presents a breakdown by category of the emissions used in the current study and a comparison with other investigations.

The major sources of $\mathrm{CO}$ are well known, although the exact magnitudes of these sources are uncertain. Emissions from fossil fuel combustion, mainly from automobile exhaust, are the best known and have been estimated by Logan et al. (1981) to lie in the range 400-1000 Tg/yr, while Seiler and Conrad (1987) have estimated 440-840 Tg/yr. CO emissions from biomass burning are much less certain and have been estimated at 310-1250 Tg/yr by Logan et al. (1981) and at $400-1600 \mathrm{Tg} / \mathrm{yr}$ by Seiler and Conrad (1987). The large range in these values reflects uncertainties in both the total amount of biomass consumed and in the amount of $\mathrm{CO}$ emitted per $\mathrm{kg}$ of biomass combusted. Another significant source of $\mathrm{CO}$ is the atmospheric oxidation of anthropogenic and natural nonmethane hydrocarbons. Although the source of $\mathrm{CO}$ resulting from the oxidation of anthropogenic hydrocarbons is probably small (Logan el al., 1981), the amount of CO generated from natural hydrocarbons has been variously estimated at 280-1200 Tg/yr by Logan et al. (1981), 400-1400 Tg/yr by Seiler and Conrad (1987) and $774 \mathrm{Tg} / \mathrm{yr}$ by Warneck (1988). Oxidation of $\mathrm{CH}_{4}$ represents a further $300-900$ 
Table 1. Carbon Monoxide and Methane Emissions ( $\mathrm{Tg} / \mathrm{yr}$ )

\begin{tabular}{lc} 
Carbon monexide & Legan et al. U9811 \\
\hline Anthropogenic fuel use & 500 \\
Oxidation of hydrocarbons & 780 \\
Biomass burning & 605 \\
Miscellaneous & 40 \\
TOTAL & 1925
\end{tabular}

\begin{tabular}{cc} 
Seiler and Conrad (1987) & Present study \\
& 570 \\
975 & 878 \\
1000 & 803 \\
117 & 0 \\
\hline 2732 & 2251
\end{tabular}

Methane
Enteric fermentation
Wetlands, rice patties, etc.
Biomass buming
Industrial
Miscellaneous
TOTAL

\begin{tabular}{cc} 
Eunget al.(1921) & Present study \\
\hline 80 & 99 \\
255 & 256 \\
55 & 55 \\
75 & 75 \\
35 & 0 \\
500 & 485
\end{tabular}

$\mathrm{Tg} / \mathrm{yr}$ source (Seiler and Conrad, 1987) of atmospheric CO. The total amount of CO generated from these major sources plus several minor ones (direct emission by plants, from the ocean, and from soils) is thought to be on the order of $3000 \mathrm{Tg} / \mathrm{yr}$ (Wameck, 1988). $\mathrm{CH}_{4}$ emissions for the current simulations have been scaled from the work of DeHaven (1980) to correspond approximately to the results of Fung et al. (1991).

\section{RESULTS AND DISCUSSION}

A total of $14 \mathrm{GChM}$ simulations have been performed with a horizontal resolution of $3.75^{\circ}$. The "base case" simulation was performed using GChM's full representation of chemical and physical processes and our best estimates for emissions. To gauge the sensitivity of the model's output when various model components are perturbed from their base case values, thirteen sensitivity simulations were performed. Results from these sensitivity simulations are presented in Table 2 as changes in the average $\mathrm{CO}$ mixing ratio in several model subdomains over the last 15 days (October $1-15,1984$ ) of the specified simulation. The sensitivity results of Table 2 indicate that the simulated $\mathrm{CO}$ is not greatly sensitive to the assumed $\mathrm{NO}_{x}$ or $\mathrm{O}_{3}$ distributions, changing no more than 5-10 percent for doubled and halved $\mathrm{NO}_{x}$ and $\mathrm{O}_{3}$ values. Further, the simulated $\mathrm{CO}$ is rather insensitive to the formulation of the boundary layer parameterization. The base case simulation contains a boundary layer eddy diffusivity parameterization that allows for the diurnal growth and collapse of the mixed layer based on local stability and surface characteristics. In the constant mixed layer simulation, the mixed layer depth was fixed at the maximum depth of the base case simulation (1740 m, the top of model layer 5) and had no diurnal variation. As evidenced by the small changes in average $\mathrm{CO}$ mixing ratio for this simulation, the lack of a diumally varying mixed layer had little impact on CO distributions. Likewise, in sensitivity simulations where the maximum mixed layer depth was forced to $1050 \mathrm{~m}$ and $2620 \mathrm{~m}$, little change was observed in the average $\mathrm{CO}$ mixing ratio.

Two simulations were performed where total $\mathrm{CO}$ emissions were increased and decreased by 50 percent. As seen in Table 2, increasing total $\mathrm{CO}$ emissions increased the global average $\mathrm{CO}$ mixing ratio 27 percent, while halving total emissions decreased the average mixing ratio by 25 percent. In the base simulation, $\mathrm{CO}$ production from $\mathrm{CH}_{4}$ oxidation was equal to 56 percent of the total $\mathrm{CO}$ emissions. Thus, increasing (decreasing) the $\mathrm{CO}$ emissions by 50 percent changes the overall $\mathrm{CO}$ source strength by +32 percent (or -32 percent). Due to the nonlinear effects of chemical feedbacks, the changes in global average $\mathrm{CO}$ mixing ratio do not respond linearly to changes in $\mathrm{CO}$ emissions. Further, three simulations were performed where each of the major $\mathrm{CO}$ emissions categories were omitted. The response of the global average $\mathrm{CO}$ mixing ratio resulting from these simulations follows that expected from the relative magnitude of emissions from each category. The largest source category is $\mathrm{CO}$ emissions from nonmethane hydrocarbon oxidation; omitting this source reduced the global average mixing ratio by 20 percent. Omitting anthropogenic and biomass burning $\mathrm{CO}$ emissions resulted in a global average mixing ratio reduction of 14 percent and 15 percent, respectively.

Figure 1 presents the $\mathrm{CO}$ mixing ratio field in the first model layer for the base case simulation, averaged over October 1-15, 1984, corresponding to the time during which the MAPS CO measurements were obtained. The surface $\mathrm{CO}$ distribution is heavily dominated by major emission sources. Mixing ratio maxima occur near the major emission sources of eastem North America, Europe, central South America, and central and southem Africa. Peak mixing ratios $>300 \mathrm{ppb}$ occur over castem North America, central South America and central and southern Africa, while remote regions (e.g., southern Pacific) exhibit mixing ratios $<45 \mathrm{ppb}$. The model produces a significant hemispheric asymmetry of $\mathrm{CO}$ mixing ratios, ranging from $75-150 \mathrm{ppb}$ in the remote northem hemisphere to $<45 \mathrm{ppb}$ in the remote southern hemisphere.

Gas-filter radiometer measurements made during the MAPS experiment correspond to a vertically integrated 
Table 2. Summary of GChM Simulations for October 1-15, 1994. For base case run, given values are average $\mathrm{CO}(\mathrm{ppbv})$ for indicated model domain. For other simulations, given values are percent changes relative to the base case.

\begin{tabular}{|c|c|c|c|c|c|c|c|}
\hline \multirow[b]{2}{*}{$\begin{array}{l}\text { Domain } \\
\text { Model Layer }\end{array}$} & \multirow[b]{2}{*}{$\begin{array}{c}\text { Global } \\
1-14 \\
\end{array}$} & \multicolumn{4}{|c|}{ Model Sub-Domain } & \multirow[b]{2}{*}{$\begin{array}{l}\text { E Europe } \\
11 \\
\end{array}$} & \multirow[b]{2}{*}{$\begin{array}{c}\text { NE Siberia } \\
11 \\
\end{array}$} \\
\hline & & $\begin{array}{c}\text { Global } \\
1\end{array}$ & $\begin{array}{c}\text { Global } \\
11 \\
\end{array}$ & $\begin{array}{c}\text { Cen Africa } \\
11 \\
\end{array}$ & $\begin{array}{c}\text { E NA } \\
11\end{array}$ & & \\
\hline \multicolumn{8}{|l|}{ Simulation } \\
\hline Base & 66.5 & 87.1 & 62.4 & 110.1 & 79.4 & 85.8 & 94.9 \\
\hline & 26.8 & 31.8 & 26.1 & 39.9 & 31.5 & 32.9 & 34.0 \\
\hline $\begin{array}{l}\text { CO Emissions } x 0.5 \\
\text { Anthropogenic } \mathrm{CO}\end{array}$ & -25.2 & -30.6 & -24.3 & -36.5 & -30.1 & -31.5 & -33.0 \\
\hline $\begin{array}{l}\text { Emissions Removed } \\
\text { Biomass Burning } \mathrm{CO}\end{array}$ & -13.8 & -18.8 & -12.0 & -1.2 & -34.1 & -30.9 & -31.0 \\
\hline $\begin{array}{l}\text { Emissions Removed } \\
\text { CO Emissions from } \\
\text { NMHC Oxidation }\end{array}$ & -14.6 & -17.4 & -15.7 & -39.8 & -6.3 & -6.8 & -5.4 \\
\hline Removed & -20.2 & -23.4 & -19.0 & -27.6 & -18.1 & -23.8 & -28.2 \\
\hline $\mathrm{NO}_{\mathrm{x}}$ mixing ratios $\times 0.5$ & 6.3 & 4.9 & 7.2 & 7.8 & 6.0 & 5.6 & 4.3 \\
\hline \multirow{2}{*}{$\begin{array}{l}\mathrm{NO}_{\mathrm{x}} \text { mixing ratios } \times 2.0 \\
\mathrm{O}_{3} \text { mixing ratios } \times 0.5\end{array}$} & -6.4 & -5.0 & -7.4 & -7.2 & -6.0 & -5.6 & -4.4 \\
\hline & 4.2 & 3.4 & 4.7 & 5.8 & 3.9 & 3.6 & 2.3 \\
\hline $\begin{array}{l}\mathrm{O}_{3} \text { mixing ratios } \times 2.0 \\
\text { Constant mixed layer }\end{array}$ & -5.0 & -4.1 & -5.6 & -6.6 & -4.8 & -4.5 & -3.4 \\
\hline $\begin{array}{c}\text { depth }=1740 \mathrm{~m} \\
\text { Maximum mixed layer }\end{array}$ & 0.2 & -2.6 & -0.2 & 0.5 & -0.8 & -1.0 & -1.7 \\
\hline $\begin{array}{c}\text { depth }=2620 \mathrm{~m} \\
\text { Maximum mixed layer }\end{array}$ & -0.1 & -2.7 & 0.5 & 0.2 & 0.9 & 1.4 & 2.0 \\
\hline \multirow{2}{*}{$\begin{array}{l}\text { depth }=1050 \mathrm{~m} \\
\text { No convective cloud } \\
\text { transport }\end{array}$} & 0.4 & 3.9 & 0.0 & 0.4 & -0.3 & -0.4 & -0.9 \\
\hline & -3.7 & 19.3 & -26.7 & -62.1 & -35.3 & -27.3 & -15.8 \\
\hline Sub-Domain & Descriptis & & Longit & de Range & Latitude & Range & \\
\hline Cen Africa & Central A & & $13^{\circ} \mathrm{E} \mathrm{t}$ & $36^{\circ} \mathrm{E}$ & $21^{\circ} S$ to & $9^{\circ} \mathrm{N}$ & \\
\hline ENA & Eastern $N$ & rth America & $92^{\circ} \mathrm{W}$ & $69^{\circ} \mathrm{W}$ & $32^{\circ} \mathrm{N}$ to & $51^{\circ} \mathrm{N}$ & \\
\hline E Europe & Eastem $\mathrm{E}$ & & $2^{\circ} \mathrm{E}$ to & & $43^{\circ} \mathrm{N}$ to & $69^{\circ} \mathrm{N}$ & \\
\hline NE Siberia & Northeast & m Siberia & $84^{\circ} \mathrm{E} t$ & $126^{\circ} \mathrm{E}$ & $54^{\circ} \mathrm{N}$ to & $77^{\circ} \mathrm{N}$ & \\
\hline
\end{tabular}

$\mathrm{CO}$ mixing ratio where the strength of the radiometer signal is a function of altitude. Since the peak signal from the $\mathrm{CO}$ instrument occurs at an altitude corresponding to level $11(\sim 350 \mathrm{hPa})$ in the model domain, the $\mathrm{CO}$ mixing ratio distribution in the mid-troposphere at model level 11 is presented in Figure 2 for the base case simulation, averaged over October 1-15. Accounting for the systematic $20-40$ percent low bias in the MAPS data, the distribution of $\mathrm{CO}$ produced by the model compares favorably with the MAPS data during this time period. Major features of the distribution that are common with the satellite data include: (i) peak CO mixing ratios occur over central South America and central and southern Africa; (ii) an extensive area of elevated CO occurs over northern Asia; (iii) no well-defined plume of elevated CO from North America is apparent; and, (iv) the lowest mixing ratios occur over the southern Pacific and the far southern Atlantic while decreased $\mathrm{CO}$ values occur in a band extending from Central America, over northern Africa, and over southem Asia.

Although the model result and the MAPS satellite data agree very well, there are some discrepancies. For example, the location of the maxima over central South America and Africa occur farther southward in the satellite data than in the model results, indicating either greater horizontal transport or a spatial difference between the model's assumed emission sources and the actual location of biomass fires during October 1984. Further, the MAPS data show indications of a $\mathrm{CO}$ plume extending from southern Africa across the far southern Indian ocean and possibly swinging northward across New Zealand and southern Australia. The model distribution also exhibits a plume originating in Africa and extending across the Indian ocean; however, the model-produced plume occurs farther north and contains $10-20 \mathrm{ppb}$ lower $\mathrm{CO}$ values than does the satellite data. Lastly, a band of lower $\mathrm{CO}$ values extending from northern Africa across eastern Europe and into central Asia is 
Flgure 1. CO mixing ratio distribution from GChM model level $1(\sim 1010 \mathrm{hPa})$ averaged over October 1-15, 1984 for the base case simulation.

Figure 2. CO mixing ratio distribution at GChM model level $11(\sim 350 \mathrm{hPa})$ averaged over October $1.15,1984$ for the base case sirnulation. Model level 11 corresponds to the altitude of maximum signal strength from the MAPS gasfilter radiometer.

clearly indicated in the MAPS data; the model result does exhibit lower mixing ratios in this region as compared to the areas of peak values, however, the $C O$ values range from $55-75 \mathrm{ppb}$ as compared to $<60 \mathrm{ppb}$ observed in the MAPS experiment.

Figure 3 presents the model produced $\mathrm{CO}$ mixing ratio distribution at model level 11 for the sensitivity simulation where the convective cloud transport parameterization was disabled within the model. The results of Figure 3 are presented with the same shading contours as Figure 2 for ease of comparison. As is readily observed, convective cloud transport plays a significant role in the amount of $\mathrm{CO}$ that is transported to model layer 11, implying that the CO distribution as observed during the MAPS experiment is largely the product of surface emissions vented rapidly to the mid-troposphere by convective activity associated with clouds. These results support the conclusions of Newell et al. (1988), Connors et al. (1989), Watson et al. (1990), and 
Figure 3. CO mixing ratio distribution at GChM model level $11(-350 \mathrm{hPa})$ averaged over October $1-15,1984$ for the no cloud convection simulation. Model level 11 corresponds to the altitude of maximum signal strength from the MAPS gas-filter radiometer.

Connors et al. (1991), that cloud convective activity serves to transport boundary layer CO into the free troposphere where it can be transported long distances away from its point of emission. As documented in Table 2, the average $C O$ mixing ratio in model layer 11 is 27 percent lower without the convective cloud parameterization enabled. Likewise, $\mathrm{CO}$ mixing ratios in the lowest model layer are 19 percent greater, indicating that in the base case simulation a substantial amount of material within the boundary layer is transported to higher model levels. In the central African sub-domain, a decrease of 62 percent in the domainaveraged $\mathrm{CO}$ mixing ratio occurred when the convective cloud parameterization was disabled, implying that a majority of the CO observed over this region in the MAPS data is brought to this level by cloud convective activity.

\section{CONCLUSION}

The GChM atmospheric chemistry and transport model has been used to analyze the mid-tropospheric CO dataset obtained from NASA's Measurement of Air Pollution by Satellites (MAPS) program. Fourteen simulations with a $3.75^{\circ}$ horizontal resolution have been performed, including a base case and 13 sensitivity runs. The model reproduces many, but not all, of the major features of the MAPS dataset. Locations of peak $\mathrm{CO}$ mixing ratios associated with biomass burning as observed in the MAPS experiment are slightly farther south than the model result, indicating either greater horizontal transport than present in the model representation or a spatial difference between the location of modeled biomass fires and actual fires. The current version of GChM was shown to be relatively insensitive to the magnitude of the prescribed $\mathrm{NO}_{\mathrm{x}}$ and $\mathrm{O}_{3}$ global distributions and very insensitive to the depth of the mixed layer as parameterized in the model. Cloud convective transport was shown to play an important role in venting boundary layer $\mathrm{CO}$ to the free troposphere. This result agrees with prior meteorological analyses of the MAPS dataset (Newell et al., 1988; Connors et al., 1989; Watson et al., 1990; and Connors et al., 1991) that have indirectly inferred the presence of convective activity through satellite-based information. Work is continuing to analyze the results of these simulations further and to perform more detailed comparisons between model results and MAPS data.

\section{Acknowledgement}

This research was funded through the Laboratory Directed Research and Development program of Pacific Northwest Laboratory. Pacific Northwest Laboratory is operated for the U. S. Department of Energy by Battelle Memorial Institute under Contract DE-ACO6-76RLO 1830. 


\section{REFERENCES}

Carmichael, G. R.,1979, Development of a regional transport/transformation/removal model for $\mathrm{SO}_{2}$ and sulfate in the eastern United States, Ph.D. dissertation, University of Kentucky, Lexington, Kentucky.

Chang, J. S., R. A. Brost, I. S. A. Isaksen, S. Madronich, P. Middleton, W. R. Stockwell, and C. J. Walcek, 1987, A three-dimensional Eulerian acid deposition model: Physical concepts and formulation, J. Geophys. Res., 92:14681-14700.

Connors, V. S., Cahoon, D. R., Reichle, H. G., Brunke, E.-G., Garstang, M., Seiler, W., and Scheel, H. E., 1991, Savanna buning and convective mixing in southern Africa: Implications for CO emissions and transport, in "Global Biomass Burning: Atmospheric, Climatic, and Biospheric Implications", J. S. Levine, ed., MIT Press, Cambridge, Massachusetts, 147-159.

Connors, V. S., Miles, T., and Reichle, H. G., 1989, Large-scale transport of a CO-enhanced air mass from Europe to the Middle East, J. Atmos. Chem., 9:479-496.

Crutzen, P. and Zimmerman, P.,1991, The changing chemistry of the troposphere, Tellus, 43AB:136-151.

DeHaven, D. A., 1980, CO and $\mathrm{CH}_{4}$ sources and their effects on the $\mathrm{CO}-\mathrm{CH}_{4}$ budgets, M.S. Thesis, University of Kentucky, Lexington, Kentucky.

Easter, R. C., 1993, Two modified versions of Bott's positive-definite numerical advection scheme, Mon. Wea. Rev., 121:297-304.

Fishman, J., and Crutzen, P. J., 1978, The origin of ozone in the troposphere, Nature, 274:855-858.

Fung, I., John, J., Lerner, J., Matthews, E., Prather, M., Steele, L., and Fraser, P., 1991, Three-dimensional model synthesis of the global methane cycle, J. Geophys. Res., 96:13033-13065.

Kitada, T. and Peters, L. K., 1982, A three-dimensional transport-chemistry analysis of $\mathrm{CO}_{\text {and }} \mathrm{CH}_{4}$ in the troposphere, in "AMS Second Symposium on the Composition of the Nonurban Troposphere", Williamsburg, Virginia, 96-101.

Kwok, H. C. W., Langlois, W. E., and Ellefsen, R. A., 1971, Digital simulation of the global transport of carbon monoxide, IBM J. Res. Develop., 15:3-9.

Lelieveld, J., and Crutzen, P.J., 1990, Influence of cloud photochemical processes on tropospheric ozone, Nature, 343:227-233.

Logan, J. A., Prather, M. J., Wofsy, S. C., McElroy, M. B., 1981, Tropospheric chemistry: A global perspective, J. Geophys. Res., 86:7210-7254.

Luec $^{i}$ n, D. J., Berkowitz, C. M., Bader, D. C., Vukovich, F. M., and Glatzmeir, G. C., 1989, The role of fair weather cumulus clouds in the long range transport of carbon monoxide and methane, American Geophysical Union Spring Meeting, Baltimore, Maryland.

Luecken, D. J., Berkowitz, C. M., and Easter, R. C., 1991, Use of a three-dimensional cloud-chemistry model to study the transatlantic transport of soluble sulfur species, J. Geophys. Res., 96:22477-22490.

Newell, R. S., Connors, V. S., Reichle, H. G., 1988, Regional studies of potential CO sources based on space shuttle and aircraft measurements, J. Atmos. Chem., 6:61-81.

Peters, L. K., and Jouvanis, A. A., 1979, Numerical simulation of the transport and chemistry of $\mathrm{CH}_{4}$ and $\mathrm{CO}$ in the troposphere, Atmos. Environ., 13:1443-1462.

Pinto, J. P., Yung, Y. L., Rind, D., Russell, G. L., Lerner, J. A., Hansen, J. E., and Hameed, S., 1983, A general circulation model study of atmospheric carbon monoxide, J. Geophys. Res., 88:3691-3702.

Reichle, H. G., Connors, V. S., Holland, J. A., Hypes, W. D., Wallio, H. A., Casas, J. C., Gormsen, B.B., Saylor, M. S., and Hesketh, W. D., 1986, Middle and upper tropospheric carbon monoxide mixing ratios as measured by a satellite-borne remote sensor during November 1981, J. Geophys. Res., 91:10865-10887.

Reichle, H. G., Connors, V. S., Holland, J. A., Sherrill, R. T., Wallio, H. A., Casas, J. C., Condon, E.P., Gormsen, B. B., and Seiler, W., 1990, The distribution of middle tropospheric carbon monoxide during early October 1984, J. Geophys. Res., 95:9845-9856.

Saylor, R. D., and Peters, L. K., 1990, The contribution of anthropogenic emissions to the global distribution of $\mathrm{CO}$ in the troposphere, Symposium on the Chemistry of the Global Atmosphere, Commission on Atmospheric Chemistry and Global Pollution, Chamrousse, France.

Saylor, R. D., and Peters, L. K., 1991, The global numerical simulation of the distribution of CO in the troposphere, "Air Pollution Modeling and Its Application VIII", H. van Dop and D. G. Steyn, eds., Plenum Press, New York, 485-496.

Seiler, W., and Conrad, R., 1987, Contribution of tropical ecosystems to the global budget of trace gases, especially $\mathrm{CH}_{4}, \mathrm{H}_{2}, \mathrm{CO}$ and $\mathrm{N}_{2} \mathrm{O}$, in "The Geophysiology of Amazonia", R.E. Dickinson, ed., John Wiley \& Sons, New York.

Seinfeld, J., 1986, "Atmospheric Chemistry and Physics of Air Pollution", John Wiley \& Sons, New York.

Walcek, C. J., and G. R. Taylor, 1986, A theoretical method for computing vertical distributions of acidity and sulfate production within cumulus clouds, J. Atmos. Sci.,43:339-355.

Warneck, P., 1988, "Chemistry of the Natural Atmosphere", Academic Press, New York.

Watson, C. E., Fishman, J., and Reichle, H. G., 1990, The significance of biomass burning as a source of carbon monoxide and ozone in the southern hemisphere tropics: A satellite analysis, J. Geophys. Res., 95:16443-16450. 


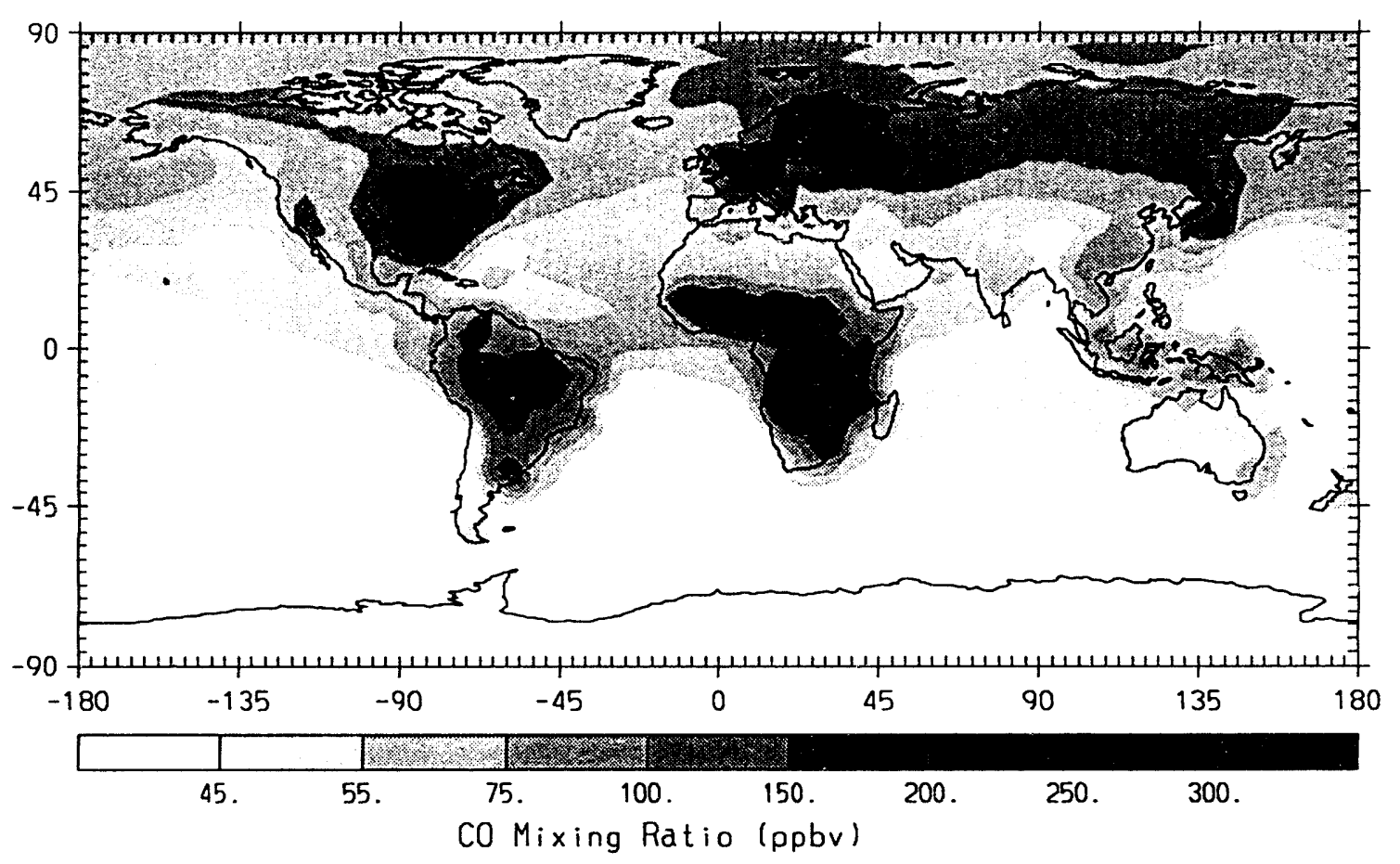




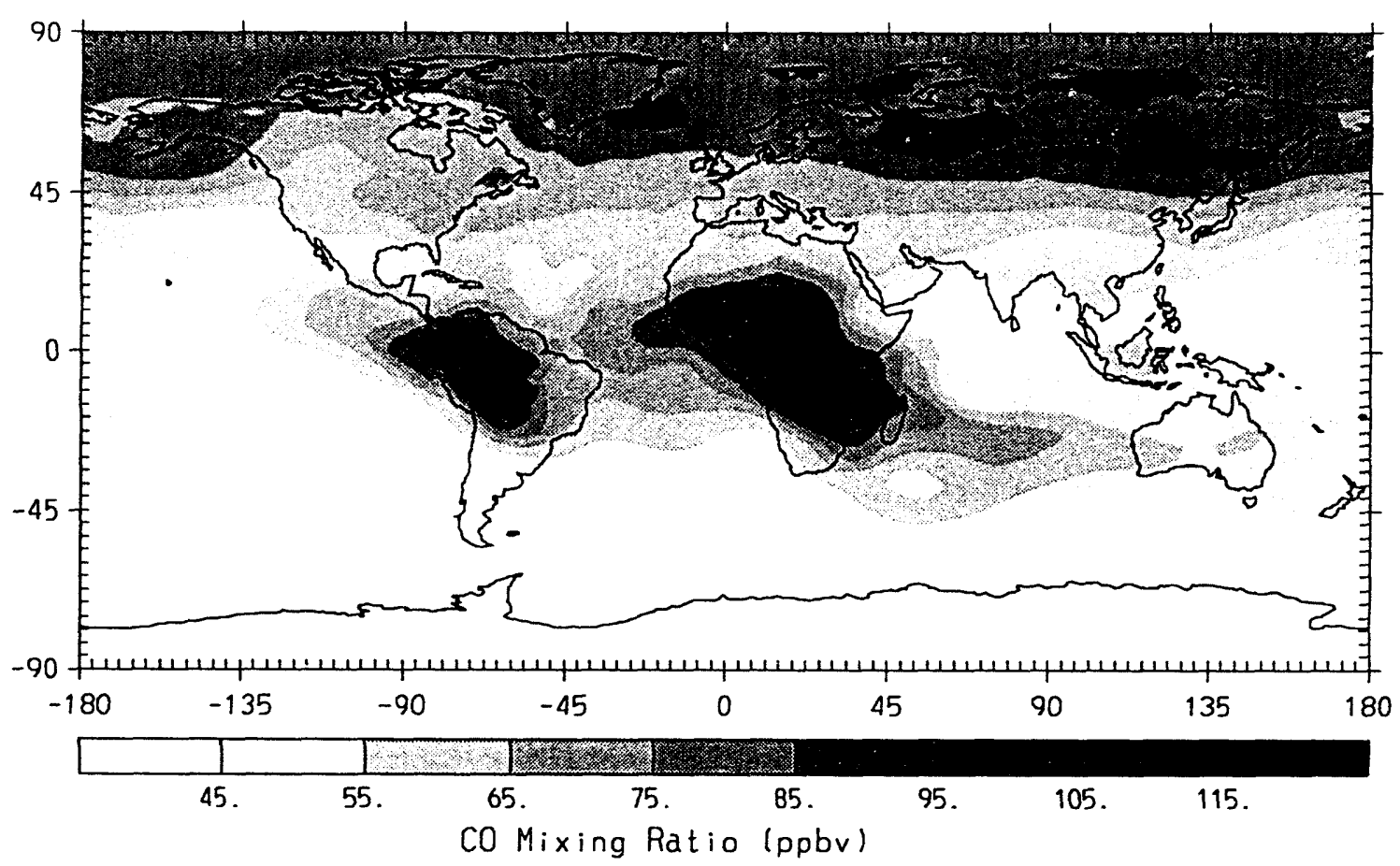




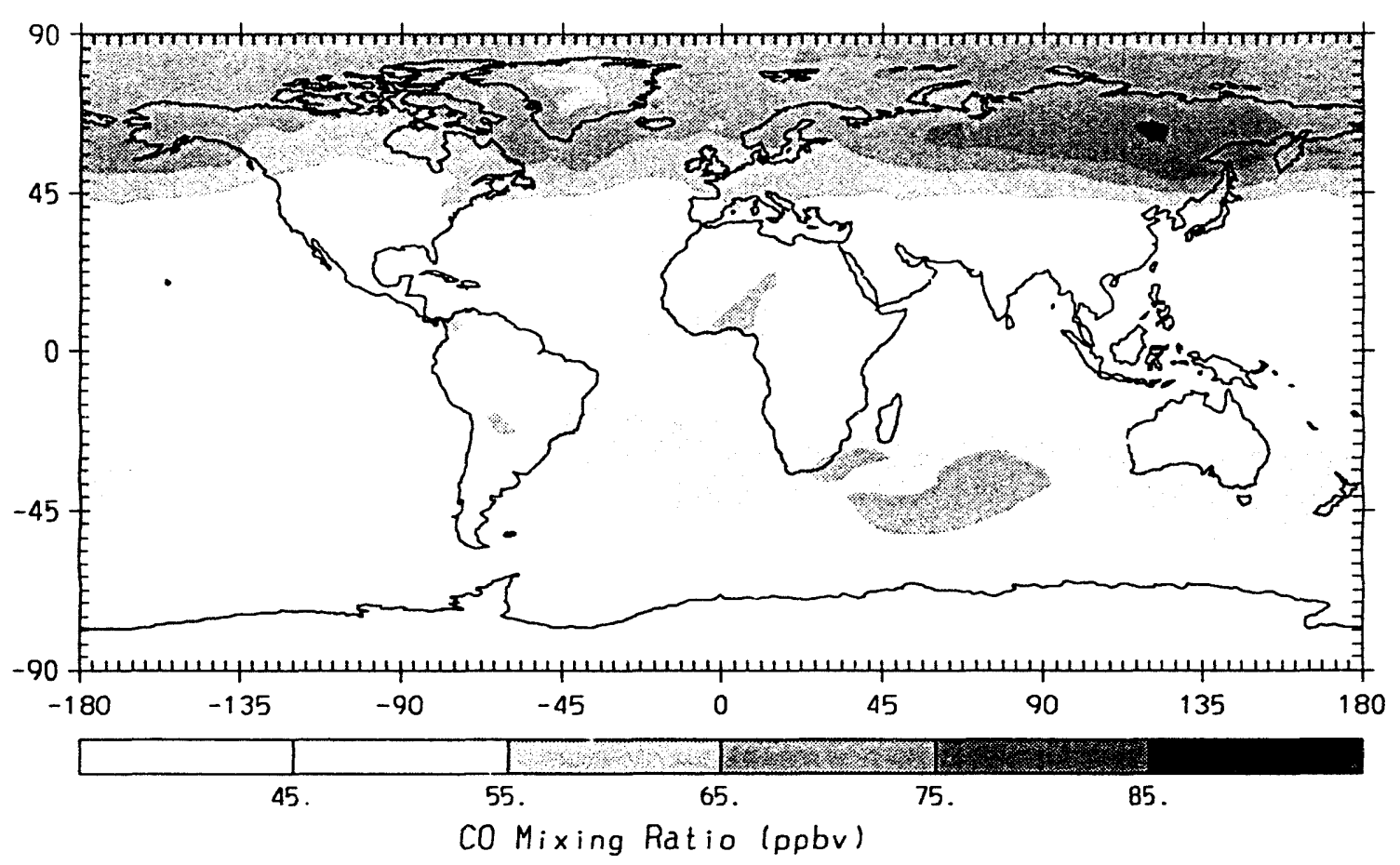




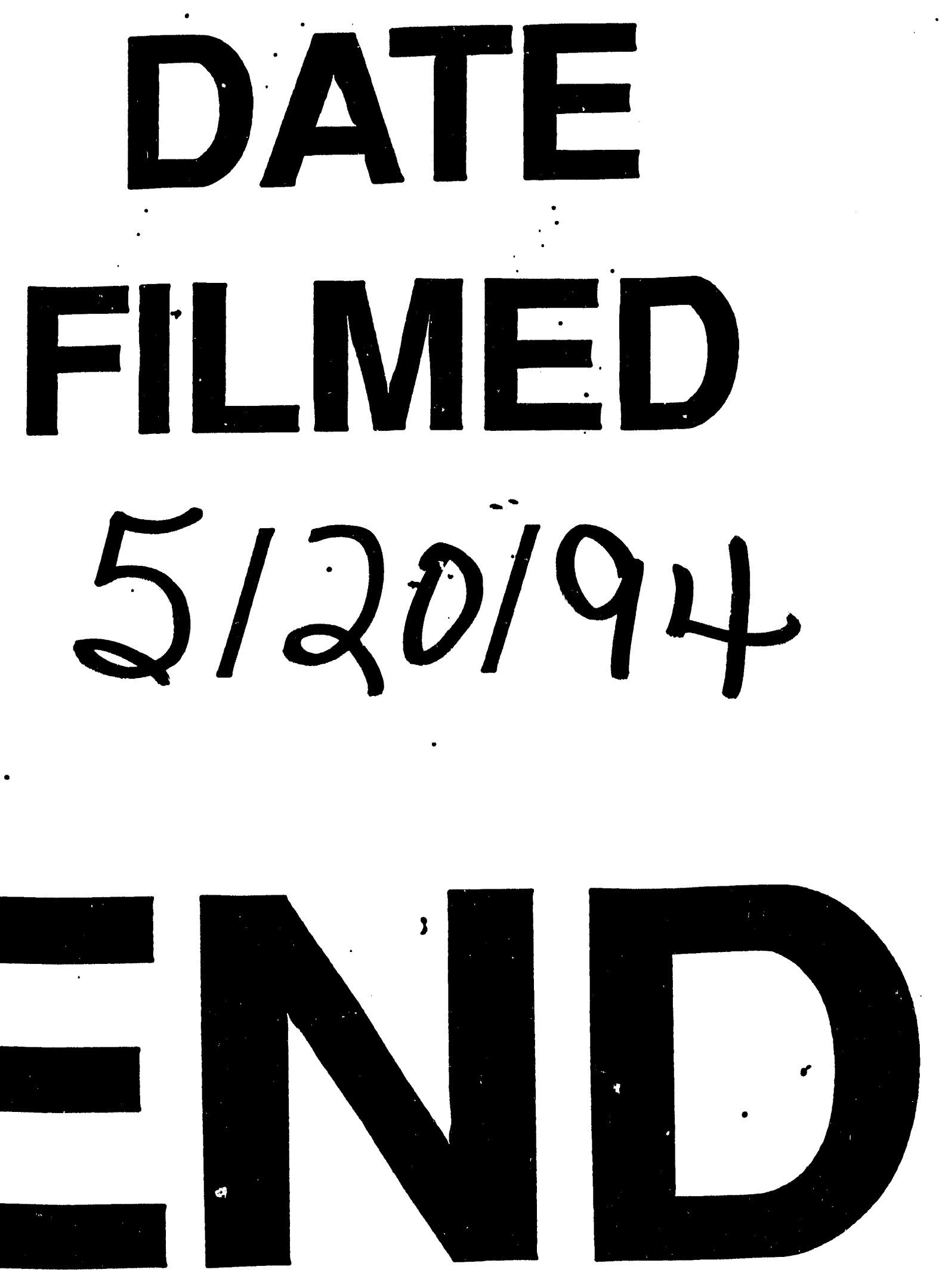


